\title{
Observasi Klinik Pemberian Jus Nanas (Ananas Comosus L. Merr) Dalam Menurunkan Kadar Kolesterol
}

\author{
Arina Yosi Moudika ${ }^{1 *}$, Akhmad Jaizzur Rijai ${ }^{1}$, Nurul Annisa², Jaka Fadraersada ${ }^{2}$ \\ ${ }^{1}$ Laboratorium Penelitian dan Pengembangan Kefarmasian "Farmaka Tropis", \\ Fakultas Farmasi, Universitas Mulawarman, Samarinda, Indonesia \\ ${ }^{2}$ Kelompok Bidang Ilmu Farmasi Klinik dan Komunitas, Fakultas Farmasi, \\ Universitas Mulawarman, Samarinda, Indonesia \\ *Email: Arinayosi@gmail.com
}

\begin{abstract}
Pineapple is a nutritious fruit contains bromelin enzyme, vitamin $C$ and fiber that can reduce hypercholesterolemia. This study found out the effect of pineapple juice (Ananas comosus L. Merr) to decrease cholesterol levels in hypercholesterolemic patients. The purpose of this study was to determine the effect of pineapple juice and it combination with drugs, as well as the comparison of the use of simvastatin in decreasing levels of hypercholesterolemia. The research method that used is quasy experimental method where treatment or intervention of respondents is carry out. The respondents was dividing into three groups. All groups were measured by initial cholesterol (Pre-Test). Group A was given simvastatin $10 \mathrm{mg}$, group B was given pineapple juice $142 \mathrm{~g} / 70 \mathrm{~kg}$ body weight, group $C$ test (combination) was given pineapple juice and simvastatin. It was administered for 6 consecutive days, then the final cholesterol measurement is carry out (Post-Test) for all groups. The results shows mean reduction percentase for the pineapple group is 14,32\%, the simvastatin group is 18,06\%, and the combination group is $18,33 \%$ so it can be concluded that pineapple can reduce cholesterol levels.
\end{abstract}

Keywords: Ananas comosus L. Merr, Cholesterol, Clinical observation, Quasy experimental, Simvastatin.

\begin{abstract}
ABSTRAK
Nanas merupakan buah berkhasiat mengandung enzim bromelin, vitamin $\mathrm{C}$ dan serat sehingga dapat mencegah hiperkolesterolemia. Penelitian ini mengetahui pengaruh pemberian jus buah nanas (Ananas comosus L. Merr) terhadap penurunan kadar kolesterol pada pasien hiperkolesterol. Tujuan penelitian ini adalah untuk mengetahui pengaruh pemberian jus buah nanas dan kombinasi dengan obat, serta perbandingan penggunaan simvastatin pada penurunan kadar hiperkolesterol. Metode penelitian yang digunakan adalah metode kuasi eksperimental dimana dilakukan perlakuan atau intervensi terhadap responden. Prosedur dalam penelitian ini yaitu dengan membagi responden menjadi tiga kelompok. Semua kelompok dilakukan pengukuran kolesterol awal (Pre-Test). Kelompok uji A diberi simvastatin 10mg, kelompok uji B diberikan jus buah nanas $142 \mathrm{~g} / 70 \mathrm{~kg} \mathrm{BB}$, kelompok uji C (kombinasi) diberikan jus buah nanas dan pemberian simvastatin.
\end{abstract}


Dilakukan pemberian selama 6 hari berturut-turut, kemudian dilakukan pengukuran kolesterol akhir (Post-Test) untuk semua kelompok. Hasil dari pengujian ini ialah \% ratarata penurunan kelompok nanas ialah $14,32 \%$, kelompok simvastatin ialah $18,06 \%$ dan kombinasi ialah 18,33\% sehingga dapat disimpulkan bahwa jus buah nanas dapat menurunkan kadar kolesterol.

Kata Kunci: Ananas comosus L. Merr, kolesterol, observasi klinik, Eksperimental quasy, Simvastatin.

DOI: https://doi.org/10.25026/mpc.v8i1.307

\section{PENDAHULUAN}

Kesehatan masyarakat secara luas menjadi hal yang sangat penting tetapi masyarakat sekarang banyak mengalami perubahan pola hidup dengan pergeseran yang cenderung beralih mengkonsumsi dari makanan tradisional ke makanan siap saji seperti fastfood dan junkfood sehingga akibat hal tersebut timbul berbagai penyakit yaitu kelebihan kolesterol atau hiperkosterol ${ }^{[1]}$. Di Indonesia sekitar 36 juta penduduk mengalami penyakit hiperkolesterol sehingga penyakit ini menjadi faktor risiko terjadinya penyakit lain contohnya gagal jantung koroner yang disebabkan oleh penumpukan plak kolesterol sehingga terjadi penyumbatan bagian pembuluh darah, hal inilah yang menjadi penyebab kematian utama di Indonesia ${ }^{[2]}$. Pada penduduk Indonesia dengan usia $\geq 15$ tahun didapatkan kolesterol total abnormal sekitar 35,9\%, HDL rendah sekitar 22,9\%, LDL tidak optimal 60,3\%, dan trigliserida abnormal sekitar $13,0 \%{ }^{[3]}$. Sekitar $70 \%$ pasien hiperkolesterolemia di Indonesia gagal mencapai sasaran kadar kolesterol sesuai panduan pengobatan $^{[4]}$.

Nanas (Ananas comosus L. Merr) ialah salah satu tumbuhan berbuah yang sangat banyak ditemui dan digemari oleh masyarakat Indonesia. Buah nanas sangat mudah dibudidayakan di daerah beriklim tropis dan dapat tumbuh pada dataran rendah ataupun tinggi. Indonesia kaya akan sumber daya alam yang dapat dimanfaatkan sebagai tanaman obat tradisional. Secara empiris, tanaman obat telah banyak dimanfaatkan masyarakat sebagai pengobatan secara turuntemurun. Salah satunya ialah tumbuhan nanas yang mengandung enzim bromelin, vitamin $\mathrm{C}$ dan serat yang tinggi. Sehingga dapat dijadikan sebagai pengobatan alternatif yang dapat mengurangi kadar kolesterol sehingga dapat mencegah terjadinya hiperkolesterolemia. Dari penelitian sebelumnya yang dilakukan pada hewan coba yaitu 12 ekor kelinci jantan lokal yang berumur 1-2 tahun dengan bobot badan (BB) berkisar antara 0,9-1,6 kg dengan pemberian jus nanas pada KI (10 g/kg BB), KII (20 g/kg BB), dan KIII (30 g/kg BB). Berdasarkan hasil penelitian secara invivo pada kelinci dengan pemberian jus buah nanas dengan berbagai dosis $10 \mathrm{~g}, 20 \mathrm{~g}$, dan $30 \mathrm{~g}$ selama 10 hari berturut-turut dan hasil analisis statistik menunjukkan perlakuan berpengaruh nyata $(\mathrm{P}<0,05)$ terhadap penurunan kadar kolesterol total darah kelinci. Sehingga dengan konsentrasi terendah yaitu $10 \mathrm{~g}$ buah nanas dapat menurunkan kadar kolesterol ${ }^{[1]}$. Namun belum ada penelitian yang dilakukan pada manusia sehingga penenlitian ini menggunakan manusia sebagai objek penelitian untuk membuktikan bahwa nanas dapat menurunkan kadar kolesterol. 


\section{METODE PENELITIAN}

\section{Alat}

Peralatan yang digunakan dalam penelitian ini adalah Alat strip kolesterol/ multicheck $\left(\mathrm{Nesco}^{\circledR}\right)$, Alcohol swab (Oneswabs $\left.{ }^{\circledR}\right)$, Blender (Philips ${ }^{\circledR}$ ), Beaker glass $\left(\right.$ Pyrex $\left.^{\circledR}\right)$, Timbangan analitik (Matrix AJ1002B ${ }^{\circledR}$ ).

\section{Bahan}

Bahan yang digunakan dalam penelitian ini adalah buah nanas dan simvastatin $10 \mathrm{mg}$.

\section{Prosedur Pengujian}

Berdasarkan metode penelitian ini dilakukan prosedur penelitian meliputi; prosedur kode etik, observasi pasien hiperkolesterol, prosedur pemilihan responden, pemberian informed consent, prosedur pembuatan dan pemberian jus buah nanas, prosedur pengambilan data karakteristik dan pola pengobatan, prosedur perlakuan prosedur analisis data, yang akan dijelaskan sebagai berikut.

\section{Prosedur pemilihan responden}

Dilakukan prosedur kode etik setelah memenuhi persyaratan yang telah ditentukan dengan dilakukan pengajuan surat permohonan penelitian dan mengajukan persetujuan etik yang diajukan ke Komisi Etik Penelitian Fakultas Kedokteran Universitas Mulawarman. Selanjutnya mengajukan surat izin observasi pada pihak Dinas Kesehatan Samarinda, lalu mengajukan surat izin observasi pada pihak Puskesmas Juanda dari Dinas Kesehatan. Melihat dan mencatat data pasien hiperkosterol di Puskesmas Juanda. Selanjutnya dilakukan pemilihan responden pada penelitian ini dipilih dengan melihat kriteria inklusi dan eksklusi. Dimana kriteria yang digunakan dalam penelitian ini masuk dalam kriteria inklusi. Sebelumnya responden telah melakukan pemeriksaan dan telah diketahui mempunyai penyakit hiperkolestrol. Kriteria inklusi yaitu termasuk dalam usia (35 - 60) tahun, penderita hiperkolesterol hanya mengkonsumsi simvastatin atau tidak mengkonsumsi obat sama sekali, dapat berkomunikasi verbal secara aktif, bersedia menjadi subjek penelitian. kriteria eksklusi yaitu pasien yang memiliki alergi terhadap buah nanas dan simvastatin, pasien yang mengkonsumsi pengobatan alternatif lainnya, pasien penderita penyakit asam lambung (maag), pasien hamil, dikumpulkan dalam lembar pengumpulan data. Selanjutnya pemberian Informed consent, subyek penelitian yang termasuk kriteria inklusi diberikan penjelasan tentang penelitian yang akan dilakukan. Kemudian pasien hiperkolesterol yang bersedia menjadi subyek penelitian diberikan surat persetujuan dengan menandatangani surat tersebut.

\section{Prosedur perlakuan}

Dilakukan prosedur pembuatan dan pemberian jus buah nanas dengan disiapkan buah nanas yang diambil dari daerah Samboja, Kampung Nanas, Samarinda, Kalimantan Timur. Dilakukan pembuatan jus nanas di Laboratorium Farmaka Tropis, Fakultas Farmasi Universitas Mulawarman, Samarinda, Kalimantan Timur dengan disiapkan alat-alat yang diperlukan lalu dikupas kulit buah nanas dan cuci bersih lalu dipotong kecil-kecil. Ditimbang buah nanas dengan konsentrasi yaitu $142 \mathrm{~g} /$ $70 \mathrm{~kg} \mathrm{BB} /$ hari konsentrasi yang didapat diambil dari penelitian sebelumnya pada kelinci dan dikonversi dosis. Diblander sehingga menghasilkan jus lalu diberikan pada responden. Selanjutnya prosedur pengambilan data karakteristik dan pola pengobatan dengan dilakukan wawancara terhadap responden penelitian untuk mendapat data karakteristik dari responden. Karakteristik meliputi; usia, jenis kelamin, kemudian obat yang digunakan untuk mengetahui pola 
pengobatan yang digunakan oleh responden penelitian. Selanjutnya prosedur perlakuan dari hasil wawancara, responden dapat dikelompokkan menjadi tiga kelompok, yaitu kelompok simvastatin 10mg, kelompok nanas dan kelompok kombinasi. Peneliti datang kerumah pasien yang bersedia menjadi subyek penelitian. Di ukur kadar kolesterol di awal pada hari pertama dengan alat multicheck $\left(\mathrm{Nesco}^{\circledR}\right)$, dikalibrasi pada setiap pengukuran dengan dongle pada sensor test darah biasanya pada display akan tertampil "ok" dan untuk keamanan dengan menggunakan alcohol swab. Dan diikuti dengan data pendamping pengukuran tekanan darah menggunakan tensimeter digital $\left(\right.$ Emeron $\left.^{\circledR}\right)$ dan di ukur setiap hari dengan pasien terlebih dahulu duduk selama 15- 20 menit dan memasukan menset pada lengan atas, sejajarkan tangan dengan jantung lalu di lakukan pengecekan tekanan darah memulai alat menekan "start" dan hasilnya akan terbaca pada alat. Kelompok uji A diberikan simvastatin pada malam hari sebelum tidur dan sesudah makan, kelompok uji B diberikan jus buah nanas pada pagi hari sesudah makan, kelompok uji $\mathrm{C}$ diberikan jus buah nanas pada pagi hari sesudah makan dan pemberian obat pada malam hari sebelum tidur dan sesudah makan dengan jeda waktu 12 jam. Dilakukan pemberian selama 6 hari berturut-turut. Di ukur kembali kadar kolesterol akhir pada responden penelitian.

\section{Prosedur Analisis Data}

Data yang diperoleh berupa karateristik pasien meliputi usia, jenis kelamin, pendidikan dan riwayat penyakit serta diperoleh data pola pengobatan yang digunakan responden penelitian. Data yang dianalisis selanjutnya adalah hasil dari pengukuran kadar kolesterol awal dan akhir setelah pemberian intervensi dibandingkan serta dilihat efek serta pengaruhnya terhadap penurunan kadar kolesterol dari responden penelitian. Hasil analisis ditampilkan dalam tabulasi dan diolah dengan metode deskriptif.

\section{HASIL DAN PEMBAHASAN}

Hasil dan pembahasan pada penelitian ini ialah berdasarkan data karakteristik responden dan analisis pengujian, data dapat dilihat sebagai berikut.

\section{Karakteristik Pasien}

\section{Jenis kelamin dan Usia}

Hasil data karakteristik jenis kelamin dan usia dapat dilihat pada tabel 1 .

Jenis kelamin merupakan salah satu faktor terjadinya kolesterol, sehingga terdapat perbedaan antara kolesterol perempuan dan laki-laki. Pada penelitian ini dilakukan pengujian pada laki-laki dan perempuan. Risiko terjadinya dislipidemia pada laki-laki lebih besar dari pada perempuan hal ini disebabkan karena pada perempuan premenopause terdapat efek perlindungan dari hormon reproduksi ${ }^{[5]}$. Akan tetapi pada pengujian ini berdasarkan persentase lebih banyak pasien perempuan dibandingkan laki-laki karena dalam penelitian ini prevalensi perempuan lebih banyak mengisi informed consent dan lebih bersedia menjadi responden dari pada laki-laki. Berdasarkan penelitian sebelumnya bahwa dari 154 responden yang mengalami peningkatan kolesterol banyak terjadi pada perempuan yaitu 56 responden $(36,70 \%)$ sedangkan pada lakilaki hanya 37 responden $(24,03 \%)$. Hal ini dapat disebabkan karena tingkat aktivitas pada laki-laki lebih tinggi sehingga kolesterol habis terbakar dengan metabolisme tubuh menjadi energi ${ }^{[6]}$.

Usia adalah salah satu parameter pemilihan sampel yang akan diteliti. Usia yang diinginkan pada penelitian kali ini adalah pasien dengan usia $(36-65$ tahun). Dari penelitian sebelumnya faktor risiko meningkatnya kadar kolesterol 
dalam darah ditemukan pada usia lebih dari 30 tahun $^{[7]}$. Menurut Depkes RI, 2009 menyatakan bahwa pada usia 26-35 tahun adalah masa dewasa awal, pada usia 36-45 tahun adalah masa dewasa akhir, pada usia 46-55 tahun adalah masa lansia awal, pada usia 56-65 tahun adalah masa lansia akhir dan pada usia lebih dari 65 tahun adalah manula ${ }^{[8]}$. Menurut World Health Organization (WHO) menggolongkan lanjut usia ada 4 yaitu usia 45-59 tahun adalah usia pertengahan (middle age), usia 60-74 tahun adalah lanjut usia (elderly), usia 75-90 tahun adalah lanjut usia tua $($ old $)$ dan usia diatas 90 tahun adalah usia sangat tua (very old). Pada penelitian ini didapatkan pasien masa dewasa akhir 7 pasien, masa lansia awal 20 pasien dan masa lansia akhir 7 pasien $^{[9]}$.

Tabel 1. Karakteristik responden berdasarkan jenis kelamin dan usia.

\begin{tabular}{clcc}
\hline Kategori & Karakteristik & Jumlah & $(\%)$ \\
\hline \multirow{2}{*}{ Jenis Kelamin } & Laki-laki & 16 & $47,1 \%$ \\
& Perempuan & 18 & $52.9 \%$ \\
& Dewasa akhir (36-45) & 7 & $20,6 \%$ \\
& Lansia awal (46-55) & 20 & $58.8 \%$ \\
& Lansia akhir (56-65) & 7 & $20,6 \%$ \\
\hline
\end{tabular}

Tabel 2. Kadar kolesterol pre dan post pemberian jus nanas pada responden laki-laki dan perempuan.

\begin{tabular}{|c|c|c|c|c|c|c|}
\hline \multirow{2}{*}{ Responden } & \multicolumn{2}{|c|}{$\begin{array}{c}\text { Kadar Kolesterol } \\
\text { Laki-laki } \\
\end{array}$} & \multirow{2}{*}{$\begin{array}{c}\text { Selisih } \\
\text { penurunan }\end{array}$} & \multicolumn{2}{|c|}{$\begin{array}{c}\text { Kadar Kolesterol } \\
\text { perempuan }\end{array}$} & \multirow{2}{*}{$\begin{array}{c}\text { Selisih } \\
\text { penurunan }\end{array}$} \\
\hline & $\begin{array}{c}\text { Pre- } \\
\text { intervensi }\end{array}$ & $\begin{array}{c}\text { Post- } \\
\text { intervensi }\end{array}$ & & $\begin{array}{c}\text { Pre- } \\
\text { intervensi }\end{array}$ & $\begin{array}{c}\text { Post- } \\
\text { intervensi }\end{array}$ & \\
\hline 1 & 210 & 199 & 11 & 206 & 147 & 59 \\
\hline 2 & 223 & 194 & 29 & 221 & 211 & 10 \\
\hline 3 & 250 & 184 & 34 & 206 & 171 & 35 \\
\hline 4 & 206 & 192 & 14 & 278 & 211 & 67 \\
\hline 5 & 246 & 204 & 42 & 212 & 184 & 28 \\
\hline 6 & 223 & 246 & -23 & 221 & 224 & -3 \\
\hline 7 & - & - & - & 225 & 265 & -40 \\
\hline 8 & - & - & - & 235 & 236 & -1 \\
\hline
\end{tabular}

\section{ANALISIS PENGUJIAN}

Berdasarkan penelitian ini di lakukan pengujian nanas, pengujian obat simvastatin dan pengujian kombinasi keduanya kepada masing-masing responden. Hasil data dalam pengujian ini dapat dilihat pada Tabel 2.

\section{Pengujian Nanas}

Pada pengujian ini responden diberikan jus buah nanas dengan masingmasing konsentrasi sesuai dengan perhitungan. Dan hasil dari pengujian ini nanas mampu menurunkan kadar kolesterol dengan rata-rata penurunan $14,32 \%$. Nanas mengandung Vitamin C berperan dalam metabolisme kolesterol dengan cara meningkatkan laju kolesterol yang dibuang dalam bentuk asam empedu yang diekresikan melalui usus halus, meningkatkan kadar HDL yang membawa kolesterol jahat LDL, dapat berfungsi sebagai pencahar sehingga meningkatkan defekasi. Selain itu nanas 
mengandung enzim bromelin yang dapat membantu dalam menurunkan kadar kolesterol dengan cara memecah lemak diusus sehingga membantu membersihkan usus dan saluran pencernaan. Sedangkan kandungan serat yang tinggi pada buah nanas dapat membantu penurunan kolesterol dengan cara mempersingkat waktu transit bahan makanan melalui saluran pencernaan, meningkatkan produksi empedu dan mengeliminasi kedalam usus untuk disekresikan sebagai feses. Hal inilah yang menurunkan reabsorpsi kolesterol dan dikonversi menjadi asam empedu ${ }^{[10]}$. Akan tetapi pada Tabel 2 pada responden laki-laki cenderung lebih sedikit penurunannya dibandingkan dengan perempuan dengan persentase rata-rata penurunan kadar kolesterol responden laki-laki ialah $11,14 \%$ dan persentase rata-rata penurunan kadar kolesterol responden perempuan ialah $17,49 \%$. Hal ini diakibatkan karena adanya hormon estrogen pada perempuan premenopause yang dapat membantu penurunan kolesterol $^{[5]}$. Dan pada pengujian ini juga terdapat peningkatan kolesterol pada Tabel 2 responden laki-laki No.6, dan responden No.6,7,8 hal ini diakibat adanya ketidakpatuhan pasien dalam menjaga pola makan dan faktor usia akibat dari metabolisme dalam tubuh semakin menurun mengakibatkan enzim lipoprotein lipase tidak dapat menghidrolisis kilomikron sehingga terakumulasi didalam darah ${ }^{[11]}$. Kilomikron berasal dari penyerapan triasilgliserol dan lipid lain di usus. Kolesterol diserap dari usus dan digabung didalam kilomikron yang dibentuk dalam mukosa, setelah kilomikron melepaskan trigliseridanya didalam adipose maka sisa kilomikron membawa kolesterol dalam hati lalu disintesis dan dieksresikan dalam bentuk bebas atau asam empedu ${ }^{[12]}$.

Tabel 3. Kadar kolesterol pre dan post pemberian simvastatin pada responden laki-laki dan perempuan

\begin{tabular}{ccccccc}
\hline \multirow{2}{*}{ Responden } & \multicolumn{2}{c}{$\begin{array}{c}\text { Kadar Kolesterol } \\
\text { Laki-laki }\end{array}$} & Selisih & \multicolumn{2}{c}{$\begin{array}{c}\text { Kadar Kolesterol } \\
\text { Perempuan }\end{array}$} & Selisih \\
\cline { 2 - 3 } & $\begin{array}{c}\text { Pre- } \\
\text { intervensi }\end{array}$ & $\begin{array}{c}\text { Post- } \\
\text { intervensi }\end{array}$ & penurunan & $\begin{array}{c}\text { Pre- } \\
\text { intervensi }\end{array}$ & $\begin{array}{c}\text { Post- } \\
\text { intervensi }\end{array}$ & \\
\hline 1 & 218 & 192 & 26 & 292 & 234 & 58 \\
2 & 224 & 196 & 28 & 236 & 214 & 22 \\
3 & 211 & 166 & 45 & 289 & 185 & 104 \\
4 & 224 & 189 & 35 & 269 & 204 & 65 \\
5 & 291 & 237 & 54 & 239 & 212 & 27 \\
\hline
\end{tabular}

Tabel 4. Kadar kolesterol pre dan post pemberian kombinasi jus nanas dan simvastatin pada responden laki-laki dan perempuan.

\begin{tabular}{ccccccc}
\hline \multirow{2}{*}{ Responden } & \multicolumn{2}{c}{$\begin{array}{c}\text { Kadar Kolesterol Laki- } \\
\text { laki }\end{array}$} & Selisih & \multicolumn{2}{c}{$\begin{array}{c}\text { Kadar Kolesterol } \\
\text { Perempuan }\end{array}$} & Selisih \\
\cline { 2 - 3 } & $\begin{array}{c}\text { Pre- } \\
\text { intervensi }\end{array}$ & $\begin{array}{c}\text { Post- } \\
\text { intervensi }\end{array}$ & penurunan & $\begin{array}{c}\text { Pre- } \\
\text { intervensi }\end{array}$ & $\begin{array}{c}\text { Post- } \\
\text { intervensi }\end{array}$ & \\
\hline 1 & 221 & 204 & 17 & 211 & 173 & 38 \\
2 & 252 & 201 & 51 & 212 & 184 & 28 \\
3 & 223 & 199 & 24 & 211 & 140 & 71 \\
4 & 250 & 246 & 4 & 249 & 140 & 109 \\
5 & 211 & 173 & 38 & 299 & 250 & 49 \\
\hline
\end{tabular}




\section{Pengujian Simvastatin}

Pada pengujian ini responden diberikan simvastatin 10mg. Dan hasilnya pada pengujian ini terdapat penurunan kadar kolesterol dengan ratarata penurunan $18,06 \%$. Pada pengujian ini pada Tabel 3 terlihat perbedaan persentase rata-rata penurunan kadar kolesterol responden laki-laki ialah $11,14 \%$ dan persentase rata-rata penurunan kadar kolesterol responden perempuan ialah $17,49 \%$, pada persentase penurunan kadar kolesterol responden perempuan lebih banyak dibandingkan dengan laki-laki. Berdasarkan pengujian sebelumnya pengunaan simvastatin pada perempuan dan laki-laki menunjukkan penurunan yang serupa dalam tingkat penurunan kadar kolesterol dan pada penelitian yang lain menunjukkan tingkat metabolisme penggunaan simvastatin lebih rendah laki-laki dibandingkan perempuan dan statin lebih banyak digunakan oleh perempuan dibandingkan dengan laki-laki ${ }^{[13]}$. Penurunan kadar kolesterol yang sedikit pada laki-laki dapat disebabkan akibat merokok. Rokok mengandung nikotin yang merupakan komponen utama dari rokok dapat meningkatkan sekresi dari katakolamin sehingga meningkatkan lipolisis dan hal ini menyebabkan meningkatnya kadar kolesterol ${ }^{[14]}$. Pada dasarnya golongan statin memang sering digunakan dalam mengobati kadar kolesterol berlebihan dalam tubuh dengan memblok secara parsial reaksi konversi 3-hidroksi-3metilglutaril koenzim A menjadi asam mevalonat sehingga proses pembentukan kolesterol dalam hati bisa dihentikan ${ }^{[15]}$. Pada pengujian ini ada beberapa responden yang mendapatkan efek samping seperti kram atau nyeri pada otot. Salah satu efek dari statin berupa nyeri otot (miopati). Nyeri otot terjadi karena statin tidak spesifik dalam menghambat atau mengurangi produksi bahan-bahan pembentuk kolesterol saja, namun statin juga dapat mengganggu metabolisme otot ${ }^{[16]}$.

\section{Pengujian Kombinasi}

Pada pengujian ini responden diberikan kombinasi jus nanas dan simvastatin $10 \mathrm{mg}$. Dan hasilnya pada pengujian ini terdapat penurunan kadar kolesterol dengan rata-rata penurunan $18,33 \%$. Pada pengujian ini pada Tabel 4 terlihat perbedaan persentase rata-rata penurunan kadar kolesterol responden laki-laki ialah $11,66 \%$ dan persentase rata-rata penurunan kadar kolesterol responden perempuan ialah $25,01 \%$. Dan hasil pengujian ini menunjukkan bahwa kombinasi jus nanas dan simvastatin lebih baik dari pada pemberian tunggal. Menurut penelitian sebelumnya ada beberapa buah yang dapat berinteraksi dengan simvastatin salah satunya itu adalah buah nanas dikarenakan dapat meningkatkan penyerapan obat dalam tubuh sehingga jumlah obat menjadi sangat tinggi di dalam tubuh ${ }^{[17]}$.

Hasil dari ketiga pengujian kelompok jus nanas, kelompok simvastatin dan kombinasi yang paling efektif dalam penurunan kadar kolesterol adalah kelompok kombinasi jus nanas dan simvastatin 10mg dikarenakan kedua pengobatan tersebut memang mempunyai aktivitas dalam penurunan kadar kolesterol dan dikombinasi akan menghasilkan efek yang lebih besar.

\section{KESIMPULAN}

Berdasarkan penelitian yang telah dilakukan maka dapat disimpulkan bahwa jus buah nanas dapat menurunkan kadar kolesterol, akan tetapi tidak lebih baik dari obat simvastatin atau pun kombinasi keduanya.

\section{DAFTAR PUSTAKA}

[1] Zuhrawati. 2014. Pengaruh Pemberian Jus Nanas (Ananas comosus) Terhadap Kadar Kolesterol Total Darah Kelinci 
Hiperkolesterolemia. Jurnal Medika Veterinaria, Vol 8, No.1.

[2] Rosyid, F N. 2009. Health Sciences. Jurnal Ilmu Kesehatan Dislipidemia.

[3] Riskesdas. 2013. Riset Kesehatan Dasar Badan Penelitian dan Pengembangan Kesehatan Kementerian Kesehatan RI. Jakarta: Bakti Husada.

[4] Yuniastuti. 2008. Gizi dan Kesehatan. Graha Ilmu: Yogyakarta.

[5] Khomsan, Ali. 2002. Dampak Terapi Estrogen pada Wanita Menopause. http://kolom.pacipic.net.id/ind/Ali_kh omsan/artikel_Ali_khosman/Dampak _Terapi_Estrogen_Pada_Wanita_M enopause.html diakses 24 Desember 2009.

[6] Amriani. 2015. Gambaran Obesitas dan Kadar Kolesterol Berdasarkan Umur dan Jenis Kelamin pada Pasien yang Berobat di Rumah Sakit Haji Medan. Jurnal Biologi Lingkungan, Industri, Kesehatan, BioLink, Vol.2(1):16-22.

[7] Al-Rahmad, Agus Hendra. 2016. Faktor Risiko Peningkatan pada Usia Diatas 30 tahun di Kota Banda Aceh. Jurnal Nutrisia, Vol. 18 No. 2, Hal 109-114.

[8] Depkes RI. 2009. Kategori Usia. Departemen Kesehatan RI: Jakarta.

[9] WHO. 2004. The World Health Organization Quality of Life (WHOQOL)-BREF. Edition John wiley \& Sons: USA.
[10]Adam, J. M. F. 2009. Dislipidemia Buku Ilmu Penyakit Dalam Jilid 3. $5^{\text {th }}$ : Departemen Ilmu Penyakit Dalam Fakultas Kedokteran Universitas Indonesia pp 1984: Jakarta.

[11]Bahri, Anwar. 2004. Dislipidemia Sebagai Faktor Risiko Jantung Koroner. Fakultas Kedokteran Universitas Sumatera Utara: Sumatera Utara.

[12]Rini, Tri Puspa. 2014. Gambaran Kadar Kolesterol Pasien yang Mendapatkan Terapi Bekam. Jurnal JOM PSIK Vol.1 No.2.

[13]Karp Igor. 2007. Perbedaan Jenis Kelamin dalam Keefektifan Statin Setelah Infark Miokard. Journal CMAJ, 176(3): 333- 338.

[14] Veena, H. 2014. Sequels of Smoking on Blood Lipid Levels in a Rural Population of South India. Research and Reviews: Journal of Medical and Health Sciences. No.3: 23-25.

[15]Diana, L. 2008. Dislipidemia-terapi obat. Jakarta.

[16]Fedacko, J. 2010. Clinical Menifestations of Adverxe Effects of Statins, Oxidative Stress and Possible Role of Antioxidants in Prevention. The Open Nutraceuticals Journal,No. 3, 154-165.

[17]Pradhani. 2017. Hati-hati Mengkonsumsi Buah dan Simvastatin. Health, Fakultas Farmasi UGM: Yogyakarta. 